\title{
Language and Gender in Political Discourse
}

\author{
Anna Knyazyan, Varduhi Hakobyan \\ Yerevan State University
}

\begin{abstract}
This article covers the problem of male and female speech differences in political discourse. Male and female politicians use different language tools in order to make the message comprehensible to the listener. Most studies of male and female language reveal women as considerably less influential than men. However, our study shows that women's role in political activity becomes increasingly important and deserves higher attention. The analysis of the speeches of political leaders gives us the idea that there are several differences which are notable in verbal communication when what we are after is gender. The article aims to identify male and female linguistic features in the speeches of two political leaders: Donald J. Trump and Hillary R. Clinton.
\end{abstract}

Key words: language, gender, political discourse, gender differences, verbal behavior.

\section{Introduction}

Sex differences are a fundamental fact of human life and it is not surprising to find them reverberated in language. There is perhaps no better way to understand human behavior as a whole than to analyze the differences between males and females. Everybody has a different style of communicating with other people. Our style depends on a lot of things: where we are from, how and where we were brought up, our educational background, our age, and it can also depend on our gender. Men and women are "metaphysically" different. Every bit, every cell in a boy is male, every cell is female in a woman, and must remain so. Women can never feel or know as men do. And in the reverse, men can never feel and know, dynamically, as women do. Men and women talk 
differently. They speak in particular ways and those ways are associated with their gender. These gender differences can be noticed in different domains, as well as in politics. Political discourse is identified by its actors or authors, that is to say politicians. Politicians seek to comply with emotions, desires, and needs of the audience. In general, the goal of politicians is not primarily to present facts but to be persuasive. Political speech is just the most evident case where the exact choice of words and expressions may influence the audience to think or even do what a political speaker wants them to think or do. The language of politicians should be viewed through gender approach which implies making a purposeful impact on audiences by using certain characteristic features. Male and female politicians try to use different linguistic tools to preserve and defend their positions in the political discourse. Political speeches need to contain highlights and memorable phrases to be remembered and to catch the attention of people beyond the special interest group. Politicians use different linguistic tools for making abstract political issue accessible to the listener and to emphasize or soften certain issues. Female and male politicians use their appropriate language in order to win their fight.

\section{Male and Female Speech Differences in Political Discourse}

Generally speaking, political power has been a masculine domain. But nowadays women's role in political activity becomes important and deserves higher attention. The analysis of the speeches of male and female political leaders gives us the opportunity to examine the differences that are notable in verbal communication when gender is concerned.

The first linguistic feature that we observed and analyzed in our study is question. In their speeches, politicians use a number of expressions of inquiry that invite a reply. Questions notify that an idea is not absolute and therefore provide opportunities for collaboration (Homles 1992). The use of expressions of inquiry is different, it depends on gender. For example, women mostly use questions to facilitate communication and express their opinions. Hillary Clinton uses tag questions expecting opportunities for collaboration. E.g.: 
"But I also, through you, want to talk to people who are still making up their minds, believe it or not, right?"

"You know, Donald Trump is doing his best to confuse, mislead, and discourage the American people. I mean, he's such a downer, right?"

"Beyond partisanship and politics, it's a hopeful, inclusive America where everyone counts and everyone has a place, right?"

"You got it. You got it. And it also means when you're knocked down, what matters is whether you get up again. I have been fighting for families and underdogs my entire life. I'm not stopping now. We're just getting warmed up, right?"'

This particular type of tag question is used by Hillary Clinton to express her own opinions. Male politicians tend to use self-dialogues. They invite listeners to participate in the conversation but they mostly use self-dialogues. For example in his speech D. Trump asks:

"In less than 8 years, 10 trillion dollars has been added. Think of it and we haven't fixed anything. We haven't fixed anything. What have we done?" and then he tries to answer to his question. "Our roads are broken, our bridges, our tunnels, our hospitals, our schools, and we have 20 trillion in debt. All-time high. That's true, our VA hospitals are in bad shape. VA is in very very bad shape and we will fix that. We are going to work on fixing that because our veterans are not treated properly. We have illegal immigrants that are treated far better in many instances than our veterans and we're not going to have that. It is revenue neutral".

The second linguistic feature that we analyzed in our study is qualifiers. Hillary Clinton and Donald Trump use a number of qualifiers in their speeches. Our study showed that $\mathrm{H}$. Clinton mostly uses relative qualifiers, such as some, 
occasionally, almost. Relative qualifiers make the statement less certain and as women's language invites input, they are characteristic of female speakers. E.g.:

"And here's some really good news. This is amazing. More than 20 million people have already voted in this election, most of those votes in the last few days, 3 million of those votes from right here in Florida. Now, you only see numbers like that when people are standing up for what they really believe in. So if all of you vote, if your friends, your family, your coworkers vote, if everyone you talk to between now and Election Day votes, we are going to make some really big history on November the $8^{t h}{ }^{\prime \prime}{ }^{3}$

Male speakers tend to be more decisive, and D. Trump also tends to use absolute qualifiers such as all, never. They make his speech more exact. E.g.:

"All Americans living lawfully in this country, including millions of patriotic hardworking immigrants, are entitled to have their jobs, their wages, and their security protected. The borders around our nation are for the benefit of all people living here today - and when those borders are erased, it's often the lawful immigrants already here who are the first to suffer lost jobs and decreased security." 4

Politicians tend to use a lot of hedges in their speeches to show that they share values with the audience and understand their beliefs. J. Coates (1997) defined hedges as linguistic forms which reflect the speaker's certainty or uncertainty about the current situation. H. Clinton tends to use such hedges as you know, well. These hedges signal the confidence that she shares values with the audience. E.g.:

"I met a young woman just yesterday in North Carolina who said, 'Nobody really explained to me and my family what I was getting into.' I hear that so much. You know, these financial aid forms, one 
is called FAFSA, it takes forever to fill out, and at the end of it you really don't know what it means? Well, we're going to be really explicit. You know, we do have technology in America. And we ought to use it more to help people understand what they're getting into and to provide alternatives so that they don't make the wrong decisions for themselves".

"And we started a fund to help fill those gaps, and, you know, we did it over so many years now, about 35 years, and we've helped thousands of people, so they didn't have to drop out". ${ }^{5}$

As we can remark, she often puts well at the beginning of the sentences, which gives her time to think about her answers.

Besides hedges, women tend to use a number of exaggerated expressive means. H. Clinton tends to use emphatic so and very, which gives a special intonation to her speech. E.g.:

"I was very honored today to earn the endorsement of John Warner, a retired Republican senator, World War II veteran, former - former secretary of the Navy who served under two Republican presidents. I served with him on the Senate Armed Services Committee. And I have the deepest respect for his patriotism. And it's a great honor. He's never endorsed a Democrat for president before. And I'm also very grateful that a number of Republicans and Independents here in New Hampshire have announced their support for this campaign. In fact, it is really an extraordinary honor that 150 Republicans here in New Hampshire are supporting this campaign because they understand how high the stakes are". ${ }^{6}$

Robin Lakoff proposed that women are more likely to use tentative speech than men (Lakoff 1975). Our study shows that D. Trump is more dominant and 
aggressive in his speech patterns than $\mathrm{H}$. Clinton. $\mathrm{H}$. Clinton makes stronger use of tentative speech. She uses this language strategy as a mechanism to generate audience participation and reaction and keep levels of high collaboration. Meanwhile, D. Trump tends to use a more direct, assertive style. He uses tentative language either to infuse humor in his speeches, or to assault his opponent. E.g.:

"Our seals took the time to move the women and children, bin Laden's family members, to safety, before destroying the helicopter. That is what honor looks like. That is America at our best. Maybe the soldiers of other nations wouldn't have bothered, or maybe they'd have taken revenge on those family members of terrorists. But that is not who we are. And anyone who doesn't understand that doesn't understand what makes our nation great"?

"Hillary is, and has been, in politics since the 70s. What's her pitch? The economy is busted? The government's corrupt? Washington is failing? "Vote for me. I've been working on these problems for 30 years. I can fix it", she says. I wasn't really sure if Hillary was going to be here tonight, because I guess you didn't send her invitation by email. Or, maybe, you did and she just found out about it through the wonder of WikiLeaks". 8

On the other hand, our research shows that the use of emotions by men is often associated with power and assertiveness. The use of emotion is mounted to express deeply felt sentiments about a particular issue or behavior. At the same time, the use of emotions by women provokes negative reactions among the audience. D. Trump uses more words of anger than H. Clinton. But she uses words of anger only in situations where values and principles are violated and the situation dictates a more direct answer. E.g.: 
"Keep calling him out and rejecting the hateful, bigoted rhetoric that seeks to pit Americans one against each other, and continue making the case in every way for our vision of an America that is "stronger together." An America where all our children have the choice to live up to their God-given potential, no matter where they come from, or what they look like, or what the circumstances of their lives have been"

"I will fight for you against the special interests, against the corrupt politicians and against the powerful insiders. Let me be your champion. In all things, it's time to put Americans first - and start taking care of each other." 10

In some situations, in order to dissolve the feeling of anger and frustration, D. Trump and H. Clinton use some swear words. But if we compare their speeches, we will understand that $D$. Trump uses more swear words than $H$. Clinton. E.g.:

"I'm running out of things but I'm going to tell you one thing. In a Donald Trump administration, there will be no bullshit. Thank you very much." 11

\section{Conclusion}

Thus, the examples which are analysed in the present article, will suffice to show that female politicians have their specific methods and appropriate use of words in order to win their fight. Male and female politicians' speech, as a whole, becomes an instrument which serves for various purposes. The investigation shows that the right choice of gender approach conveys vividness and interest to the politician's language, proving its impact on the audience. In some cases the boundaries between masculinity and femininity are erased or manifested implicitly. Sometimes female politicians try to cross these limits - 
this is conditioned by the fact that female political leaders tend to preserve and defend their positions by imitating masculine manners of speech.

\section{Notes:}

1. Hillary Clinton. Remarks at the Manor Complex in Wilton Manors, Florida. Available at: <http://www.presidency.ucsb.edu/ws/index.php?pid=119697> [Accessed September 2017].

2. Donald J. Trump. Remarks on Proposals for the First 100 Days in Office at the Eisenhower Complex in Gettysburg, Pennsylvania. Available at: <http://www. presidency.ucsb.edu/ws/index.php?pid=119875 $>$ [Accessed September 2017]

3. Hillary Clinton.Remarks at the Manor Complex in Wilton Manors, Florida. Available at: <http://www.presidency.ucsb.edu/ws/index.php?pid=119697> [Accessed September 2017].

4. Donald J. Trump. Remark at Henderson Pavilion in Henderson, Nevada. Available at: <http://www.presidency.ucsb.edu/ws/index.php?pid=119169> [Accessed September 2017].

5. Hillary Clinton. Remarks at the University of New Hampshire in Durham. Available at: <http://www.presidency.ucsb.edu/ws/index.php?pid=119164> [Accessed September 2017].

6. Hillary Clinton. Remarks at the University of New Hampshire in Durham. Available at: <http://www.presidency.ucsb.edu/ws/index.php?pid=119164> [Accessed September 2017].

7. Hillary Clinton Talks about American Exceptionalism at Amerian Legion Convention. Available at: $<$ https://hillaryspeeches.com/2016/08/31/>[Accessed September 2017].

8. Donald J. Trump. Remarks at the WNC Agricultural Center's Davis Event Center in Fletcher, North Carolina. Available at: <http://www.presidency. ucsb.edu/ws/index.php?pid=119185> [Accessed September 2017].

9. Hillary's vision for America. Available at: <https://www.hillaryclinton. com/briefing/updates/2016/09/08/in-kansas-city-clinton-reflects-on-her-faithand-the-belief-that-we-are-stronger-together/> [Accessed September 2017] .

10. Donald J. Trump. Remarks at a Rally at Canton Memorial Civic Center in Canton, Ohio. Available at: <http://www.presidency.ucsb.edu/ws/ index.php?pid $=119190>$ [Accessed September 2017]. 
11. Donald J. Trump. Remarks on Immigration at the Phoenix Convention Center in Phoenix, Arizona. Available at: <http://www.presidency.ucsb.edu/ws/index. php?pid=119805 $>$ [Accessed September 2017].

\section{References:}

1. Holmes J. (1992) Women, Men and Politeness. New York: Longman.

2. Coates, J. (1997) Language and Gender Oxford: Blackwell.

3. Lakoff R. (1975) Language and Woman's Place. New York: Harper and Row.

\section{Ltiqnid la qtiantipn puinupulquid pununıjpnud}

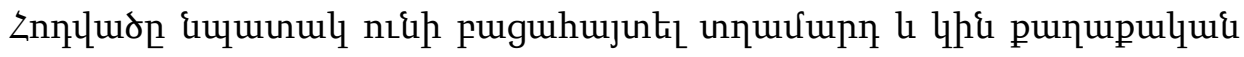

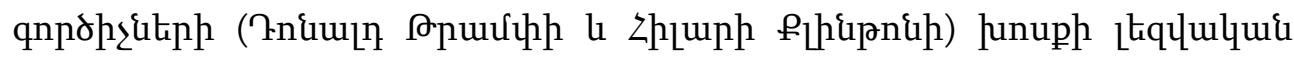

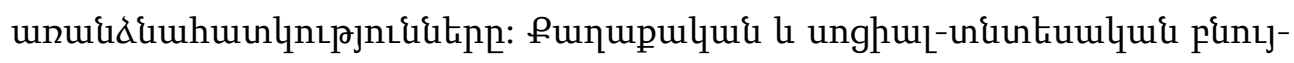

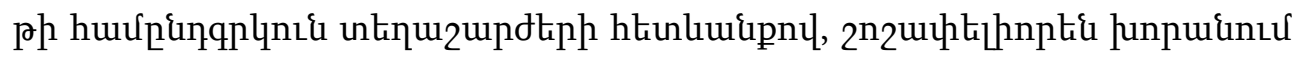

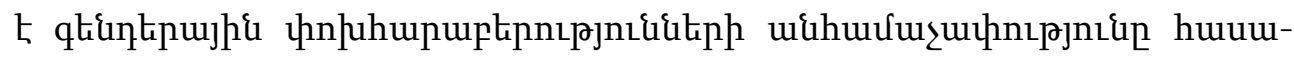

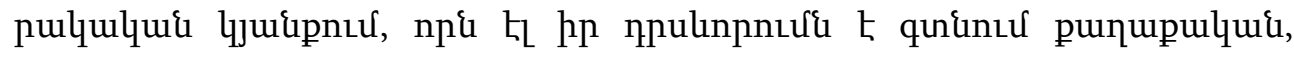

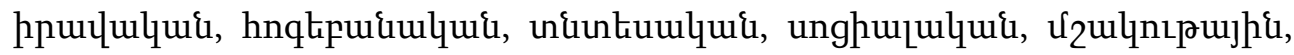

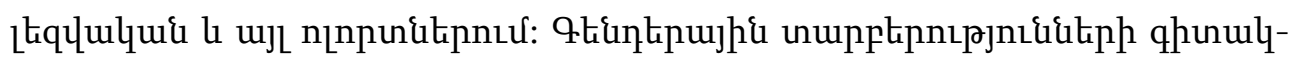

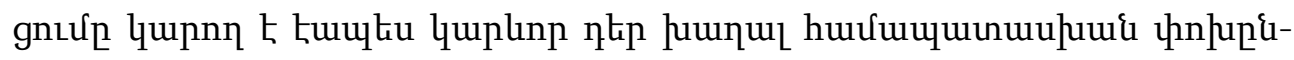

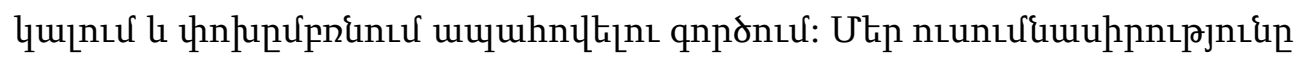

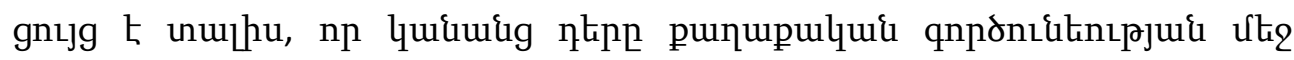

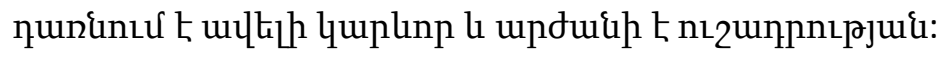

